Management and Economics Journal

E-ISSN : 2598-9537 P-ISSN : 2599-3402

Journal Home Page: http://ejournal.uin-malang.ac.id/index.php/mec

Volume 4 Number 3, December 2020

\title{
The Effect of Organizational Culture and Supplier Integration to Supply Chain Performance
}

Nasar Buntu Laulita Faculty of Economics Batam International University, Batam Center, Batam, Indonesia. nasar bl@yahoo.com.sg

\begin{abstract}
This study aims to investigate the influence of four types of organizational cultures and supplier integration to supply chain performance. The methodology of this research is an explanatory study by testing two hypotheses. The data's were collected from a convenience samples of 171 manufacturing companies of total 850 companies in Kepulauan Riau Province being represented by manager in supply chain management divisions. Data's were collected using questionnaire and technical data analysis using SEM (Structural Equation Model). The result of this study found that: (1) Group Culture and Rational Culture affect Supply Chain Performance positively and significantly but Development Culture and Hierarchical Culture are not significant; (2) Supplier Integration affects Supply Chain Performance positively and significantly. The managerial implication of this research is as a guidance for decision maker in the company or manager in the supply chain management to implement suitable organizational culture and consider the supplier integration as a strategic to improve Supply Chain Performance.
\end{abstract}

Keywords: Organizational Culture, Supplier Integration, Supply Chain Performance, Structural Equation Model

\section{INTRODUCTION}

United Nations Statistics Division (2018) said that Indonesia in year 2016 was one of the fifteen countries whose manufacturing industry contributed more than $10 \%$ to the Gross Domestic Product (GDP) where Indonesia ranked fourth with a contribution of $21.3 \%$ after South Korea (29.3\%), China (27.5\%) and Germany (26.9\%). Riau Islands Province it self had a contribution above the national average of $36 \%$ from Gross Regional Domestic Product (GRDP) in the year 2018. The above factors made it difficult for companies in Indonesia and also the Riau Islands province to compete with competitors in other countries if they are not able to choose the right strategy related to supply chain management, especially in the relationship of buyers and suppliers to operate efficiently by minimizing losses (Al-Tit, 2017). The decline of Indonesia's competitiveness in the manufacturing industry can be seen from the decline in the growth of the manufacturing industry in the computer, electronic and optical goods industry by $0.51 \%$ in year 2019 
according to data from the Central Statistics Agency (2019), where manufacturing industries are the main industries in the Riau Islands Province. Riau Islands Province as the outer province of Indonesia that having advantages because of its location which is directly adjacent to a neighboring country must also have an advantage to be able to compete with other countries as an investment destination. From Batam and Riau Islands Department of Manpower data's, there are 170 companies that have closed or moved from 2014-2018 and some of reasons are the inability to compete with other companies abroad because they are not competitive in price, quality or fulfillment of customer demand flexibility, so that some companies move their businesses to another place in another country.

According to Stock et al. (2010), Danese (2013), Kumar et al. (2017), Vanpoucke et al. (2017) and He et al. (2016), the effectiveness of supplier integration is an important strategy for companies that want to achieve excellence performance. Lee et al. (2007) also states that supplier integration is the best strategy in achieving reliable supply chain performance. Supplier integration ( $\mathrm{SI}$ ) continues to be a challenge for many companies because problems in supplier relationship management can threaten shareholder assets (Kull et al., 2013). Supplier integration refers to the application of partnering with suppliers to share resources, develop procedures and behavior between organizations, and develop new capabilities to meet customer requirements (Flynn et al. (2010). Vanpoucke et al. (2017) further explained that investment in integration with suppliers has potential to provide better operational performance than investment integration with customers.

Fawcett et al. (2008) and McCarter et al. (2005) states that organizational culture will give higher contribution to supplier integration than customer integration. Some studies also specifically examine the influence of organizational culture to company performance such as Al-Tit (2017), Gochhayat et al. (2017), Bag (2018) and Zhao et al. (2018). In general, previous studies used the Competing Value Framework (CVF) to explain the organizational culture that was popularized by Quinn \& Rohrbaugh (1981) and Quinn \& Rohrbaugh (1983) which consisted of four cultural dimensions, they are development culture, group culture, hierarchical culture, and rational culture. In influencing the overall organizational culture, Bag (2018) explains that organizational culture plays an important role in the success of relationship management with suppliers, as well as with Prajogo \& McDermott (2011) along with Al-Tit (2017) which states that there is a positive relationship in organizational culture relations and company supply chain operational performance. Different results stated by Zhao et al. (2018) whose the research focused on the influence of the application of organizational culture on company performance, where the results of the study conclude that the application of organizational culture has a negative effect on firm value or financial performance of the company but has a positive effect on firm's innovation output. Research Zhao et al. (2018) this contrasts with the research of Graham et al. (2017) which states that $91 \%$ of executives view that culture is very important for their company and $71 \%$ of them consider culture as one of the total three or five important factors in influencing company value. 
Miguel \& Brito (2011) explained that the supply chain management literature was born from the positive impact of its application on company performance, where performance shows the efficiency and effectiveness of overall supply chain management. Operational steps are included because they are directly related to the relationship between supply chain partners and include steps for new product development (Mclvor \& Humphreys, 2004; Jajja et al., 2016), waiting times (Humphreys et al., 2004; Jajja et al., 2016), delivery performance (Tan et al., 2002; Jajja et al., 2016), product response and reliability (Shin et al., 2000; Jajja et al., 2016), customer satisfaction (Flamholtz \& Kannan-Narasimhan, 2005; Jajja et al., 2016) and the manufacturing cycle time (Naylor et al., 1999; Jajja et al., 2016). In addition, Gawankar et al. (2017) in detail divides supply chain management performance measurements based on traditional measurements (supply chain flexibility, supply chain integration, response to customers, efficiency, quality, product innovation, market performance) and relationship measurements (relationship quality, supplier performance) or it's measured gemnerally by quality and market performance and operational performance (Jajja et al., 2016).

Based on the above, the research objectives are to study the effect of organizational culture and supplier integration to supply chain performance as shown in the research framework on figure 1 and the research hypothesis as mentioned below.

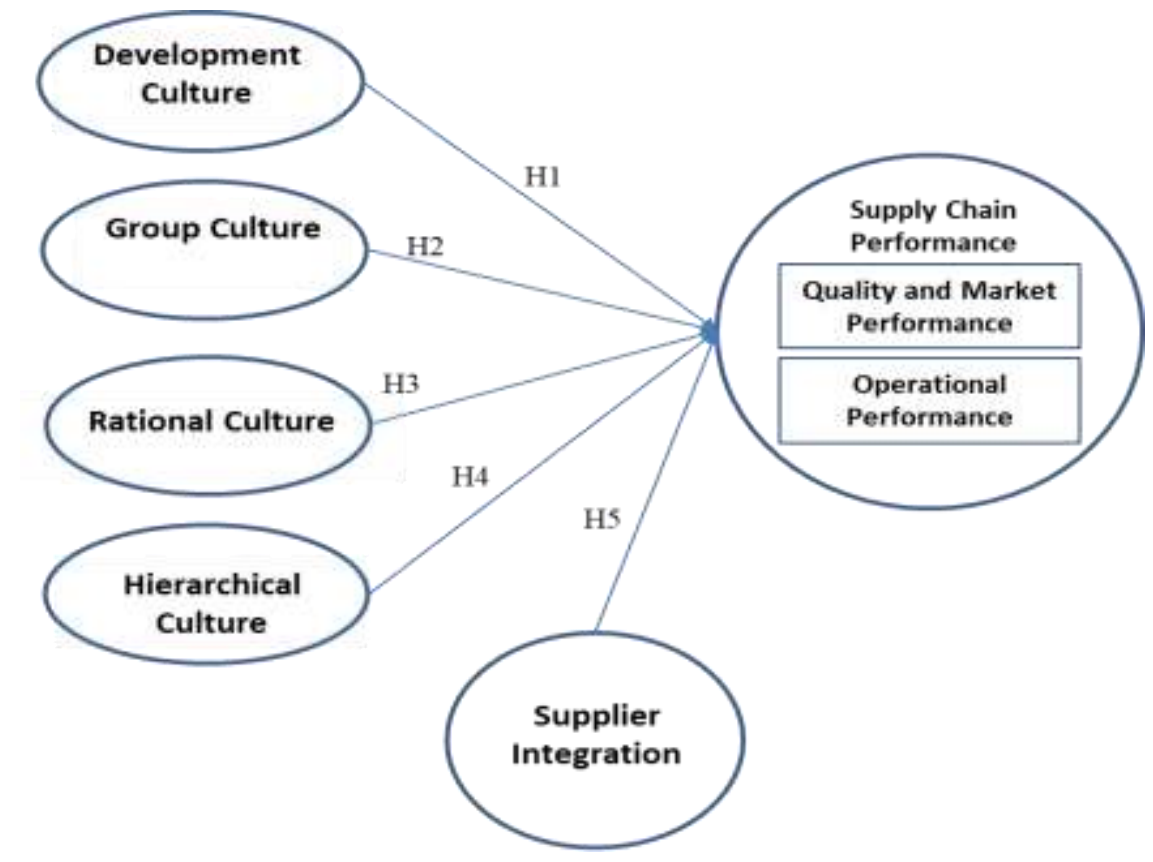

Figure 1. Research Framework

H1: Development Culture significantly influences supply chain performance

$\mathrm{H} 2$ : Group culture significantly influences supply chain performance

H3: Rational culture has a significant effect on supply chain performance 
H4: Hierarchical culture significantly influences supply chain performance

H5: Supplier integration significantly influences supply chain performance

The structural equation model of the study is shown in the figure below.

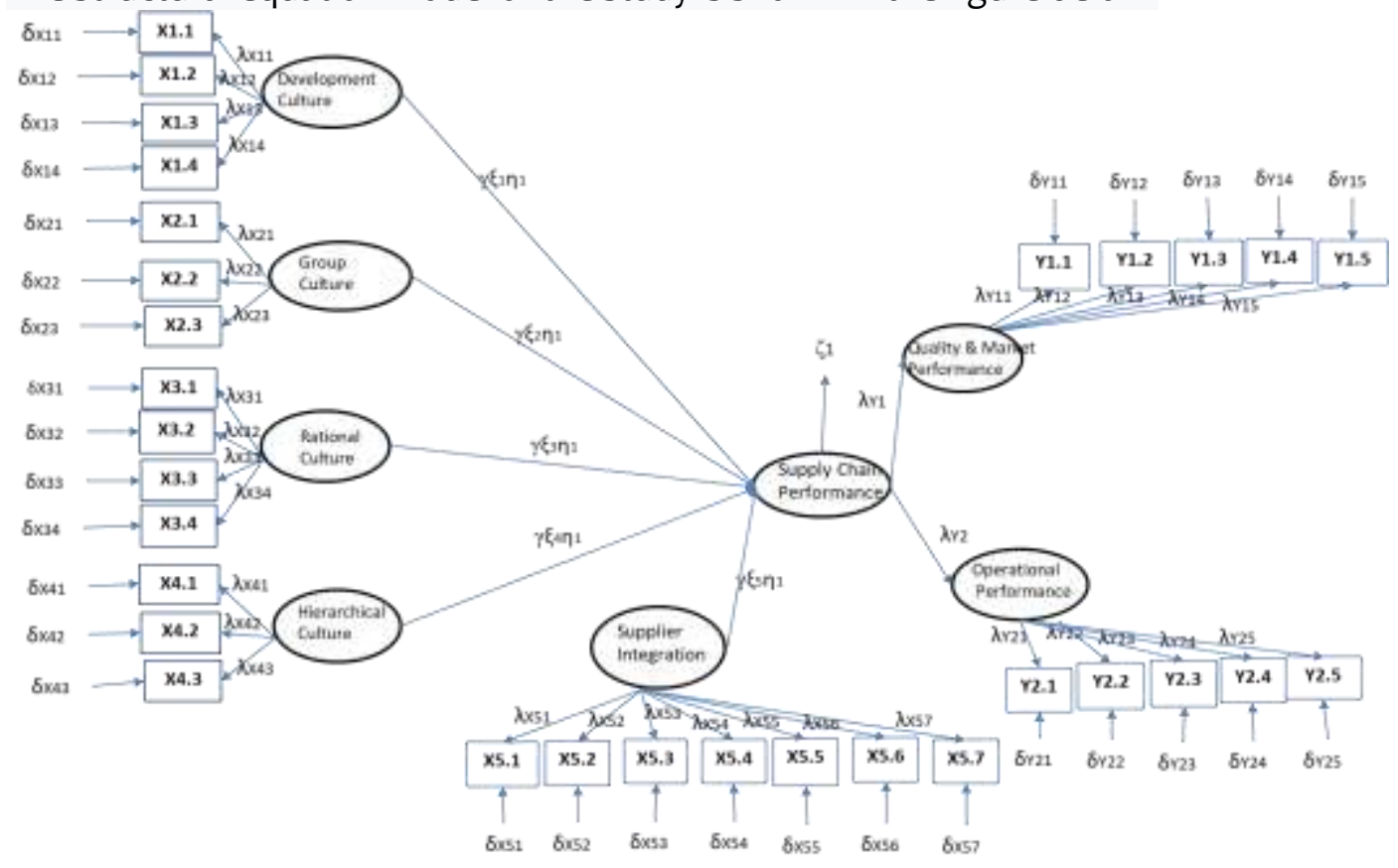

Figure 2. Structural Equation Model

\section{METHODOLOGY}

\section{Population, Sample and Data Collection}

The population of this research are those companies in Riau Island Province which implement supply chain management. Data's were collected using an online survey method with a minimum sample size of 100 as required for two until five latent variable (Hair et al., 2018). The questionnaire was distributed online to supply chain management person in charge on 850 companies by using Google forms and email. A total of 175 questionnaires were collected and after removing four samples incomplete data 171 respondents' responses could be used for further analysis.

\section{Measurement of Variables}

This study adapts the research from Cao et al. (2015) which explains that the dimensions of organizational culture are spelled out in four dimensions, namely development culture with four indicators, group culture with three indicators, rationale culture with four indicators and hierarchical culture with three statement indicators. Also, variable of supplier integration was adapted from Cao et al. (2015) with seven indicators. Statement indicators about supply chain performance were adopted from Jajja et al. (2016) with two dimensions named quality and market performance with five indicators and operational performance with five indicators also. All statement items in the questionnaire were distributed to respondents using five Likert scales. 
Statistical Calculation

Data were analyzed using structural equation model with maximum likelihood estimation (MLE) in the relationship of each dimension of organizational culture and supplier integration to supply chain performance with SPSS 24.0 and Lisrel 8.7 software.

\section{RESEARCH RESULTS}

Table 1. Company Profile

\begin{tabular}{|c|c|c|}
\hline & Freq & $\%$ \\
\hline \multicolumn{3}{|c|}{ Length of Established } \\
\hline $0-5$ years & 4 & 2,3 \\
\hline $5-10$ years & 24 & 14 \\
\hline$>10$ years & 143 & 83,3 \\
\hline \multicolumn{3}{|l|}{ Industry Types } \\
\hline Electronic & 85 & 49,7 \\
\hline Plastic & 48 & 28,1 \\
\hline Metal & 27 & 15,8 \\
\hline Others & 11 & 6,4 \\
\hline \multicolumn{3}{|c|}{ Number of employee } \\
\hline $100-250$ & 53 & 31 \\
\hline $251-500$ & 98 & 57,3 \\
\hline$>500$ & 20 & 11,7 \\
\hline \multicolumn{3}{|l|}{ Sales/Year } \\
\hline USD $200 \mathrm{~K}-4 \mathrm{M}$ & 78 & 45,6 \\
\hline$>$ USD $4 \mathrm{M}$ & 93 & 54,4 \\
\hline \multicolumn{3}{|c|}{$\%$ of oversea key supplier } \\
\hline$<50 \%$ & 45 & 26,3 \\
\hline $50 \%-75 \%$ & 78 & 45,6 \\
\hline$>75 \%$ & 48 & 28,1 \\
\hline
\end{tabular}


Table 2. Supply Chain Manager Profile

\begin{tabular}{lcc}
\hline & Frequence & $\%$ \\
\hline Gender & & \\
Male & 96 & 56,1 \\
Female & 75 & 43,9 \\
Education & & \\
$<$ Degree & 34 & 19,9 \\
Degree & 132 & 77,2 \\
Master Degree/PhD & 5 & 2,9 \\
& & \\
Working Period in Current Company & & 7 \\
$<5$ years & 12 & 64,9 \\
$5-10$ years & 111 & 28,1 \\
$>10$ years & 48 & \\
& & 0 \\
Total Working Period & & 9,9 \\
$<5$ years & 0 & 90,1 \\
\hline - 10 years & 17 & \\
$>10$ years & 154 & \\
\hline
\end{tabular}

Respondents' perceptions for each dimension of organizational culture, namely development culture, group culture, rational culture and hierarchical culture, as well as transformational supply chain leadership style, and supply chain performance are shown in Tables 3, 4, 5, 6, 7 and 8 below.

Table 3. Development Culture

\begin{tabular}{ccc}
\hline Indicator & \multicolumn{1}{l}{ SD } & Mean \\
\hline DC1 & 0,808 & 4,082 \\
DC2 & 0,807 & 4,041 \\
DC3 & 0,781 & 4,047 \\
DC4 & 0,762 & 4,158 \\
\hline
\end{tabular}

Table 4. Group Culture

\begin{tabular}{ccc}
\hline Indicator & SD & Mean \\
\hline GC1 & 0,777 & 4,158 \\
GC2 & 0,739 & 4,175 \\
GC3 & 0,711 & 4,152 \\
\hline
\end{tabular}


Table 5. Rational Culture

\begin{tabular}{ccr}
\hline Indicator & SD & Mean \\
\hline $\mathrm{RC} 1$ & 0,801 & 4,129 \\
$\mathrm{RC2}$ & 0,771 & 4,129 \\
$\mathrm{RC} 3$ & 0,801 & 4,129 \\
$\mathrm{BR} 4$ & 0,765 & 4,164 \\
\hline
\end{tabular}

Table 6. Hierarchical Culture

\begin{tabular}{ccc}
\hline Indicator & SD & Mean \\
\hline $\mathrm{HC}_{1}$ & 0,761 & 4,094 \\
$\mathrm{HC} 2$ & 0,769 & 4,140 \\
$\mathrm{HC}_{3}$ & 0,781 & 4,035 \\
\hline
\end{tabular}

Table 7. Supplier Integration

\begin{tabular}{clr}
\hline Indicator & SD & Mean \\
\hline SI1 & 0,642 & 4,275 \\
SI2 & 0,716 & 4,199 \\
SI3 & 0,619 & 4,263 \\
SI4 & 0,792 & 4,053 \\
SI5 & 0,752 & 4,152 \\
SI6 & 0,628 & 4,316 \\
SI7 & 0,646 & 4,316 \\
\hline
\end{tabular}

Tabel 8. Supply Chain Performance

\begin{tabular}{cccc}
\hline Dimension & Indicator & SD & Mean \\
\hline MP & MP1 & 0,626 & 4,234 \\
& MP2 & 0,675 & 4,181 \\
& MP3 & 0,642 & 4,228 \\
& MP4 & 0,662 & 4,310 \\
OP & MP5 & 0,648 & 4,322 \\
& OP1 & 0,633 & 4,304 \\
& OP2 & 0,720 & 4,228 \\
& OP3 & 0,621 & 4,222 \\
& OP4 & 0,658 & 4,328 \\
& OP5 & 0,635 & 4,234 \\
\hline
\end{tabular}

Confirmatory Factor Analysis (CFA) is to determine the validity and reliability of indicators for each research construct and the model's Goodness of Fit are shown in Tables 9, 10, 11 and 12 . 
The Effect of Organizational Culture and Supplier Integration .....

Table 9. Validity and Reliability Test of Organizational Culture First Construct

\begin{tabular}{cccccc}
\hline Dms & $\lambda$ & AVE & CR & VT & RT \\
\hline DC & 0,95 & 0,51 & 0,79 & Valid & Good \\
GC & 0,55 & & & Valid & \\
RC & 0,55 & & & Valid & \\
HC & 0,72 & & & Valid & \\
\hline
\end{tabular}

Table 10. Validity and Reliability Test of Supplier Integration

\begin{tabular}{cccccc}
\hline Ind & $\lambda$ & AVE & VT & CR & RT \\
\hline SI1 & 0,75 & & Valid & & \\
SI2 & 0,66 & & Valid & & \\
SI3 & 0,82 & & Valid & & \\
SI4 & 0,68 & 0,55 & Valid & 0,85 & Good \\
SI5 & 0,71 & & Valid & & \\
SI6 & 0,78 & & Valid & & \\
SI7 & 0,77 & & Valid & & \\
\hline
\end{tabular}

Table 11. Validity and Reliability Test of Supply Chain Performance First Construct

\begin{tabular}{cccccc}
\hline Dms & $\lambda$ & AVE & CR & VT & RT \\
\hline KMP & 0,94 & 0,86 & 0,91 & Valid & Good \\
KO & 0,91 & & & Valid & \\
\hline
\end{tabular}

The results of the table show that each construct indicator has a loading factor value $\geq$ $0,50, A V E$ value $\geq 0,50$ and $C R$ value $\geq 0,60$. It can be concluded that all indicators are valid and reliable and can measure constructs accurately (Hair et al., 2018). Hair et al. (2018) also states that the model is fit if the result of testing found at least one of absolute fit, incremental fit and parsimony measurement test results that exist. Based on the results of the above table, the goodness of fit test results can be stated that the research model is declared good fit because it is seen from the values of RMSEA, GFI, $\mathrm{NNFI}, \mathrm{CFI}, \mathrm{IFI}, \mathrm{NFI}, \mathrm{AIC}$ and CAIC, so the model is declared to pass the goodness of fit test and can be done to the next test. 
Tabel 12. Goodness of Fit Test

\begin{tabular}{|c|c|c|c|}
\hline Item & Target of measurement & Estimation Result & Conclusion \\
\hline \multicolumn{4}{|c|}{ Measurement of Absolute Fit } \\
\hline RMSEA & $0,05-0,08$ & 0,071 & Good Fit \\
\hline $\mathrm{Cl}$ for & $0,00-0,10$ & $0,00-0,01$ & Good Fit \\
\hline \multicolumn{4}{|l|}{ RMSEA } \\
\hline GFI & $>0,80,>0,90$ & 0,99 & Good Fit \\
\hline \multicolumn{4}{|c|}{ Measurement of Incremental Fit } \\
\hline NNFI & $>0,90$ & 0,98 & Good Fit \\
\hline CFI & $>0,90$ & 1,00 & Good Fit \\
\hline IFI & $>0,90$ & 1,00 & Good Fit \\
\hline $\mathrm{NFI}$ & $>0,80,>0,90$ & 0,99 & Good Fit \\
\hline \multicolumn{4}{|c|}{ Measurement of Parsimony Fit } \\
\hline AIC and & Model result $<$ model & AIC: $55,38<56,00$ & Good Fit \\
\hline CAIC & saturated & CAIC: $154,78<171,97$ & \\
\hline
\end{tabular}

From the results of the hypothesis test with Lisrel 8.7, the results obtained are as in table 13 below:

Table 13. Result of Hipothesis Test

\begin{tabular}{cccc}
\hline Hipothesis & Coefficient $(\gamma)$ & t-value & Result \\
\hline $\mathrm{H}_{1}$ & $-0,19$ & $-1,39$ & $\mathrm{H} 1$ is not significant \\
$\mathrm{H}_{2}$ & 0,21 & 2,34 & $\mathrm{H} 2$ is significant \\
$\mathrm{H}_{3}$ & 0,32 & 2,98 & $\mathrm{H} 3$ is significant \\
$\mathrm{H} 4$ & $-0,02$ & $-0,13$ & $\mathrm{H}_{4}$ is not significant \\
$\mathrm{H} 5$ & 0,38 & 5,66 & $\mathrm{H} 5$ is significant \\
\hline
\end{tabular}

Hypotheses testing and path coefficients show the direct effects of Development Culture affects supply chain performance, Group culture affect supply chain performance, Rational culture affect supply chain performance, Hierarchical culture affect supply chain performance, Supplier integration affect supply chain performance. The $t$ value of statistics is shown in Table 13. Development Culture has no significant effect on supply chain performance with a path coefficient of $-0,19$ and $t$ count value of $-1,39<1,96$. The study results not support H1. This result support Zhao et al. (2018) state that the application of organizational culture has a negative effect on firm value or financial performance of the company.

Group culture has a significant effect on supply chain performance with a path coefficient of 0,21 and a t count value of 2,34 $>1,96$. The results of study support $\mathrm{H} 2$. This results support some previuos studies which find relationship group culture and supply chain perforrmance (Quinn \& Rohrbaugh (1981) and Quinn \& Rohrbaugh (1983).

Rational culture has a significant effect on supply chain performance with a path coefficient of 0,32 and a t count value of 2,98 > 1,96. The results of study support $\mathrm{H} 3$. This results support Quinn \& Rohrbaugh (1981) and Quinn \& Rohrbaugh (1983), 
Fawcett et al. (2008) and McCarter et al. (2005) states that organizational culture will give higher contribution to supplier integration than customer integration.

Hierarchical culture has no significant effect on supply chain performance with a path coefficient of $-0,02$ and a t count value of $-0,13<1,96$. The study results not support $\mathrm{H} 4$. This results not support Bag (2018) explains that organizational culture plays an important role in the success of relationship management with suppliers.

Supplier integration has a significant effect on affect supply chain performance with a path coefficient of 0,38 and a t count value of 5,66 $>1,96$. The results of study support H5. This results support Prajogo \& McDermott (2011) along with Al-Tit (2017) which states that there is a positive relationship in organizational culture relations and company supply chain operational performance.

\section{CONCLUSION}

This research objectives are to study the effect of organizational culture and supplier integration to supply chain performance. Based on the hypothesis test conducted, it can be concluded that supplier integration is really important on supply chain management strategy in the manufacturing company because it can improve supply chain performance. This research also concludes the importance to determine the application of an appropriate organizational culture in the manufacturing company, where the development culture and hierarchical culture are not significantly affect supply chain performance manufacturing companies in Riau Islands Province while group culture, rational culture and supplier integration significantly affect the supply chain performance. This research provides input to the supply chain managers in the manufacturing companies especially in the big company or multinational company about the relationship between the application of group culture, rational culture and supplier integration to improve supply chain performance and the lack of effective to apply the development culture and hierarchical culture in the company.

\section{REFERENCES}

Al-Tit, A. A. (2017). Factors affecting the organizational performance of manufacturing firms. International Journal of Engineering Business Management, 9, 1-9.

Bag, S. (2018). Supplier Management and Sustainable Innovation in Supply Networks: An Empirical Study. Global Business Review, 19(3), 176-195.

Cao, Z., Huo, B., Li, Y., \& Zhao, X. (2015). The impact of organizational culture on supply chain integration: A contingency and configuration approach. Supply Chain Management: An International Journal, 20(1), 24-41.

Danese, P. (2013). Supplier integration and company performance: A configurational view. Omega, 41(6), 1029-1041.

Fawcett, S. E., Magnan, G. M., \& McCarter, M. W. (2008). Benefits, barriers, and bridges to effective supply chain management. Supply Chain Management: An International Journal, 13(1), 35-48. 
Flamholtz, E., \& Kannan-Narasimhan, R. (2005). Differential Impact of Cultural Elements on Financial Performance. European Management Journal, 23(1), 50-64.

Flynn, B. B., Huo, B., \& Zhao, X. (2010). The impact of supply chain integration on performance: $A$ contingency and configuration approach. Journal of Operation Management, 28, 58-71.

Gawankar, S. A., Kamble, S., \& Raut, R. (2017). An investigation of the relationship between supply chain management practices (SCMP) on supply chain performance measurement (SCPM) of Indian retail chain using SEM. Benchmarking: An International Journal, 24(1), $257-295$.

Gochhayat, J., Giri, V. N., \& Suar, D. (2017). Influence of Organizational Culture on Organizational Effectiveness: The Mediating Role of Organizational Communication. Global Business Review, 18(3), 1-12.

Graham, J. R., Harvey, C. R., Popadak, J., \& Rajgopal, S. (2017). Corporate culture: Evidence from the field. National Bureau Economics Research, (No. w23255).

Hair, J. F., Babin, B. J., Anderson, R. E., \& Black, W. C. (2018). Multivariate Data Analysis (8th ed.). Pearson Prentice Hall.

He, Y., Sun, H., Ni, W., \& Ng, S. C. H. (2016). Re-examining the effects of supplier integration on operations performance: A relational view. International Journal of Operations \& Production Management, https://doi.org/10.1108/ IJOPM-04-2016-0205.

Humphreys, K., Wing, S., McCarty, D., Chappel, J., Gallant, L., Haberle, B., \& Weiss, R. (2004). Self-help organizations for alcohol and drug problems: Toward evidence-based practice and policy. Journal of Substance Abuse Treatment, 26(3), 151-158.

Jajja, M. S. S., Kannan, V. R., Brah, S. A., \& Hassan, S. Z. (2016). Supply chain strategy and the role of suppliers: Evidence from the Indian sub-continent. Benchmarking: An International Journal, 23(7), $1658-1676$.

Kull, T. J., Ellis, S. C., \& Narasimhan, N. (2013). Reducing behavioural constraints to supplier integration: A socio-technical systems. Journal of Supply Chain Management, 49(1), 64-86.

Kumar, V., Chibuzo, E. N., Garza-Reyes, J. A., Kumari, A., Rocha-Lona, L., \& Lopez-Torres, G. C. (2017). The impact of supply chain integration on performance: Evidence from the UK Food Sector. Procedia Manufacturing, 11, 814-821.

Lee, C. W., Kwon, I. G., \& Severance, D. (2007). Relationship between Supply Chain Performance and Degree of Linkage among Supplier, Internal Integration and Customer. Supply Chain Management International Journal, 12, 444-452.

McCarter, M., Fawcett, S. E., \& Magnan, G. M. (2005). The effect of people on the supply chain world: Some overlooked issues. Human Systems Management, 24(3), 197-208. 
Mclvor, R., \& Humphreys, P. (2004). The Implications of Electronic B2B Intermediaries for the Buyer-Supplier Interface. International Journal of Operations \& Production Management, 24(3), 241-269.

Miguel, P. L. S., \& Brito, L. A. L. (2011). Supply Chain Management measurement and its influence on Operational Performance. Journal of Operations and Supply Chain Management, 4(2), 56-70.

Naylor, J. B., Naim, M. M., \& Berry, D. (1999). Leagility: Integrating the lean and agile manufacturing paradigms in the total supply chain. International Journal Production Economics, 62, 107-118.

Prajogo, D., \& McDermott, C. (2011). The relationship between multidimensional organizational culture and performance. International Journal Operational Production Management, 31(7), 712-735.

Quinn, R. E., \& Rohrbaugh, J. (1981). A competing values approach to organizational effectiveness. Public Productivity Report, 5(2), 122-140.

Quinn, R. E., \& Rohrbaugh, J. (1983). A spatial model of effectiveness criteria: Towards a competing values approach to organizational analysis. Management Science, 29(3), 363377.

Shin, H., Collier, D. A., \& Wilson, D. D. (2000). Supply management orientation and supplier/ buyer performance. Journal of Operations Management, 18(3), 317-333.

Stock, J. R., Boyer, S. L., \& Harmon, T. (2010). Research opportunities in supply chain management. Journal of the Academy of Marketing Science, 38(1), 32-41.

Tan, K. C., Lyman, S. B., \& Wisner, J. D. (2002). Supply chain management: A strategic perspective. International Journal of Operations and Production Management, 22(6), 614631.

Vanpoucke, E., Vereecke, A., \& Muylle, S. (2017). Leveraging the impact of supply chain integration through information technology. International Journal of Operations \& Production Management, 37(4), $510-530$.

Zhao, H., Teng, H., \& Wu, Q. (2018). The effect of corporate culture on firm performance: Evidence from China. China Journal of Accounting Research, 11, 1-19. 